Article

\title{
Variability of Rainfall Erosivity and Erosivity Density in the Ganjiang River Catchment, China: Characteristics and Influences of Climate Change
}

\author{
Xianghu $\mathrm{Li}^{1,2, *(1)}$ and Xuchun Ye ${ }^{3}$ \\ 1 Key Laboratory of Watershed Geographic Sciences, Nanjing Institute of Geography and Limnology, \\ Chinese Academy of Sciences, Nanjing 210008, China \\ 2 School of Natural Resources, and Department of Earth and Atmospheric Sciences, \\ University of Nebraska-Lincoln, Lincoln, NE 68583-0987, USA \\ 3 State Key Laboratory of Hydrology-Water Resources and Hydraulic Engineering, Hohai University, \\ Nanjing 210098, China; yxch2500@163.com \\ * Correspondence: xhli@niglas.ac.cn; Tel.: +86-25-8688-2117
}

Received: 11 December 2017; Accepted: 1 February 2018; Published: 3 February 2018

\begin{abstract}
Soil erosion is one of the most critical environmental hazards in the world. Understanding the changes in rainfall erosivity (RE) and erosivity density (ED), as well as their affecting factors, at local and catchment scales in the context of climate warming is an important prerequisite of soil erosion prevention and soil loss risk assessment. The present study identified the variability and trends of RE and ED in terms of both time and space in the Ganjiang River catchment over the period of 1960-2012, and also analyzed and discussed the impact of climate change. The results show that RE and ED in the catchment had great monthly variations and high year-to-year variability. Both presented long-term increasing trends over the entire study period. The highest RE and ED were observed in June and in the eastern and northeast parts of the catchment, which indicated that June was the most susceptible month for soil erosion in this area and the lower reaches of the Ganjiang River was the riskiest area for soil erosion. Finally, the East Asian summer monsoon and climate change were highly correlated with changes in RE and ED.
\end{abstract}

Keywords: rainfall erosivity; erosivity density; spatiotemporal distribution; trend; Ganjiang River catchment

\section{Introduction}

Soil erosion by water is one of the most important land degradation problems and a critical environmental hazard in modern times, and it has severely restricted the development of global society and economy [1]. Soil erosion not only destroys land resources [2] and increases the risks posed by the blockage of rivers, but also causes the deterioration of water quality because of pesticides, fertilizers, and nutrients carried by sediment [3,4]. Statistics indicate that approximately 10 million ha of cropland are lost each year because of soil erosion at the global scale [5], especially in Asia, Africa, and South America, where the erosion is more serious [6]. Therefore, the prediction of soil erosion is particularly important for soil erosion control and land management projects and provides an effective tool for preventing and avoiding a series of adverse effects such as land degradation and river pollution [7-10].

The Universal Soil Loss Equation (USLE) [11] and its revised form (RUSLE) [12] are the most widely used methods for predicting and evaluating soil erosion worldwide [10]. As a numerical description of climate impact on soil loss, rainfall erosivity (RE) is one of the most important factors used in the USLE and RUSLE [13,14]; it combines the influence of precipitation duration, magnitude, and intensity [15] and can directly reflect the potential of soil erosion caused by rainfall [11,16]. 
The temporal variation in RE is the basis for distinguishing the effects of climate on long-term erosion rates in the region, and its spatial distribution can help identify the areas with higher erosivity potentials $[10,17]$. Therefore, accurate estimations of rainfall erosivity are fundamental for a better understanding of the erosion ability of certain rainfall events [18].

According to the definition of Wischmeier and Smith [11], rainfall erosivity is a multi-annual average index that measures the kinetic energy and intensity of rainfall in order to describe the effect of rainfall on sheet and rill erosion. A continuous rainfall data series with a time resolution of at least 30 minutes and a period of more than 22 years is recommended for the calculation of RE $[11,12,19]$. However, such data are difficult to obtain on a large scale in many parts of the world [20], and the calculation of RE is time-consuming and laborious because of the complicated and tedious computational procedure [21,22]. As an alternative, a considerable number of statistical regression equations between RE and the routine meteorological records of annual, monthly, or daily rainfall data [22-28], as well as some derivative indices including the Fournier index (F), the Modified Fourier Index (MFI), and the Precipitation Concentration Index (PCI) [18,21,29-34], have been proposed to overcome this problem [18]. Several studies have evaluated the performance of the regression equations using coarser temporal resolution rainfall data $[7,35,36]$ and have found that the accuracy of the estimation of RE values based on annual and monthly rainfall data is not satisfactory [10,37]. Daily rainfall data is preferably used to estimate rainfall erosivity, and the accuracy of RE has been widely verified $[38,39]$.

The variability of rainfall erosivity affects agriculture, forestry, hydrology, water management, and ecosystem services [40]. Understanding its spatial distribution and temporal trends is especially critical for soil erosion risk assessment and soil conservation planning [10,41,42]. Therefore, the spatiotemporal variation of rainfall erosivity has been discussed worldwide. For example, Panagos et al. [43] and Ballabio et al. [40] estimated the rainfall erosivity in Europe based on the best available datasets and investigated their spatial and temporal variability. They found that a sudden increase of erosivity occurred in major parts of Europe in May, with the highest values registered during the summer months; these values were almost four times higher than those recorded in winter. Panagos et al. [15] presented a monthly rainfall erosivity map for Greece and found that the spatial variability of RE was high in Greece. Klik et al. [44] found that the rainfall erosivity in New Zealand showed a large spatial variability, mainly related to the climatic and topographic differences throughout the territory. Meshesha et al. [17] indicated that the long-term average annual erosivity showed a general decreasing trend in the recent period from 2000 to 2010 compared to the previous 20 years (1980-1999) in Ethiopia. da Silva [21] found that December and January had the highest erosivity values for most of the Brazilian territory and that the lowest values were observed from June to September. Moreover, Diodato et al. [19] developed a parsimonious rainfall erosivity model using long-term erosivity data derived from 10 stations in western Germany. Bonilla and Vidal [45] presented a rainfall erosivity map for most of the cultivated land in Chile. Ramos and Durán [46] evaluated rainfall erosivity based on different time intervals for the Penedès region (in northeast Spain). Also, in China, numerous studies on this issue have been conducted either on the national scale $[41,47,48]$ or the regional scale, such as in the Yunnan Plateau region [10], the Chinese Loess Plateau [14,18], and dryland regions [49].

However, most previous research has been conducted at continental or national scales. Due to the huge differences in geomorphology, climate, and driving forces, the variability of erosive rainfall and its erosivity are different across geographical regions [50,51]. The spatiotemporal heterogeneity of rainfall erosivity downscaled from the large-scale results are coarser for a given local catchment. For example, from the nationwide perspective, many studies have documented that erosive rainfall in the past decades has intensified in most regions of China [52-54], but at the local scales, the changing trends of erosive rainfall were more complex. For example, Xie et al. [47] assessed and compared the performance of different parameters developed in other parts of the world for rainfall erosivity estimation and revealed that parameters from the study of Zhang et al. [24] tended to overestimate the rainfall erosivity. The reason for the overestimation may be due to their use of a surrogate instead of 
the measured value of $\mathrm{EI}_{30}$. Therefore, Xie et al. [47] also suggested that the models and coefficients developed in one catchment may need to be recalibrated carefully before they are implemented in other places. Moreover, many research investigations have revealed that the size and the number of sub-watersheds, as well as the rain gauge density, also have a great impact on the runoff and sediment yield simulations, especially for steep watersheds $[55,56]$. Therefore, quantifying the trends and variability in erosive rainfall and its erosivity at local and catchment scales is highly required [51].

The Poyang Lake basin is one of the most serious soil erosion areas in the south of China [57]. According to the third remote sensing investigation of soil erosion conducted by the Jiangxi Provincial Water Resources Bureau, the main type of erosion in the Poyang Lake basin is water erosion, and the area with soil erosion is about $3.35 \times 10^{4} \mathrm{~km}^{2}$, accounting for $20.03 \%$ of the total acreage [58]. The increasingly serious soil erosion conditions in Poyang Lake basin could be, on one hand, attributed to the strong influence of the East Asian summer monsoon. Frequent heavy and extreme precipitation events have caused serious soil losses and land degradation during the past decades. On the other hand, possible factors also include the complex terrain and soil type in the basin. The topography in the Poyang Lake basin varies from highly mountainous and hilly areas (with a maximum elevation of $2200 \mathrm{~m}$ above sea level) to alluvial plains in the lower reaches of the primary watercourses. The soils in the basin are mainly composed of red soil [59], which has a low infiltration rate of precipitation and is degraded and erosion-prone [60]. Thus, it is quite necessary to extend the previous studies at the local scale to provide a better understanding of variations in rainfall erosivity.

It is also very practical to assess the spatial distribution and temporal trends of rainfall erosivity in the Poyang Lake basin. As is known, the Poyang Lake basin is an important national agricultural production region and also plays a significant role in the sustainable development of the economy and ecology of southeast China. Accurately quantifying the spatiotemporal distribution of rainfall erosivity and erosivity density in this area is of great significance for controlling soil erosion and protecting regional (and even national) agriculture and food security. Therefore, the objectives of this study are (1) to estimate the RE and erosivity density (ED) in the Poyang Lake basin using the daily rainfall data from 1960-2012 and (2) to investigate their trends and variability in time and space and analyze their dependence on climate change. Outcomes of this study are expected to improve the understanding of $\mathrm{RE}$ and ED at the local scale and provide useful reference and valuable information for soil erosion risk assessment and soil conservation planning in the Poyang Lake basin, as well as in other regions.

\section{Study Area and Data}

The Ganjiang River catchment is the largest sub-catchment of the Poyang Lake basin, which is located within $24^{\circ} 29^{\prime}-29^{\circ} 21^{\prime} \mathrm{N}$ and $113^{\circ} 30^{\prime}-116^{\circ} 45^{\prime} \mathrm{E}$ in southeast China (Figure 1) and has a drainage area of $83,374 \mathrm{~km}^{2}$ above the Waizhou hydrologic station. The Ganjiang River is the largest tributary of the Poyang Lake water system; it extends for $750 \mathrm{~km}$ and contributes almost $55 \%$ of the total discharge into Poyang Lake [61]. The topography of the catchment is complex and the elevation ranges from 11 to $1997 \mathrm{~m}$ above sea level. The catchment develops between mountains and along rivers, and low hills lie in the central part of the catchment, whereas alluvial plains govern the lower reaches [62]. 

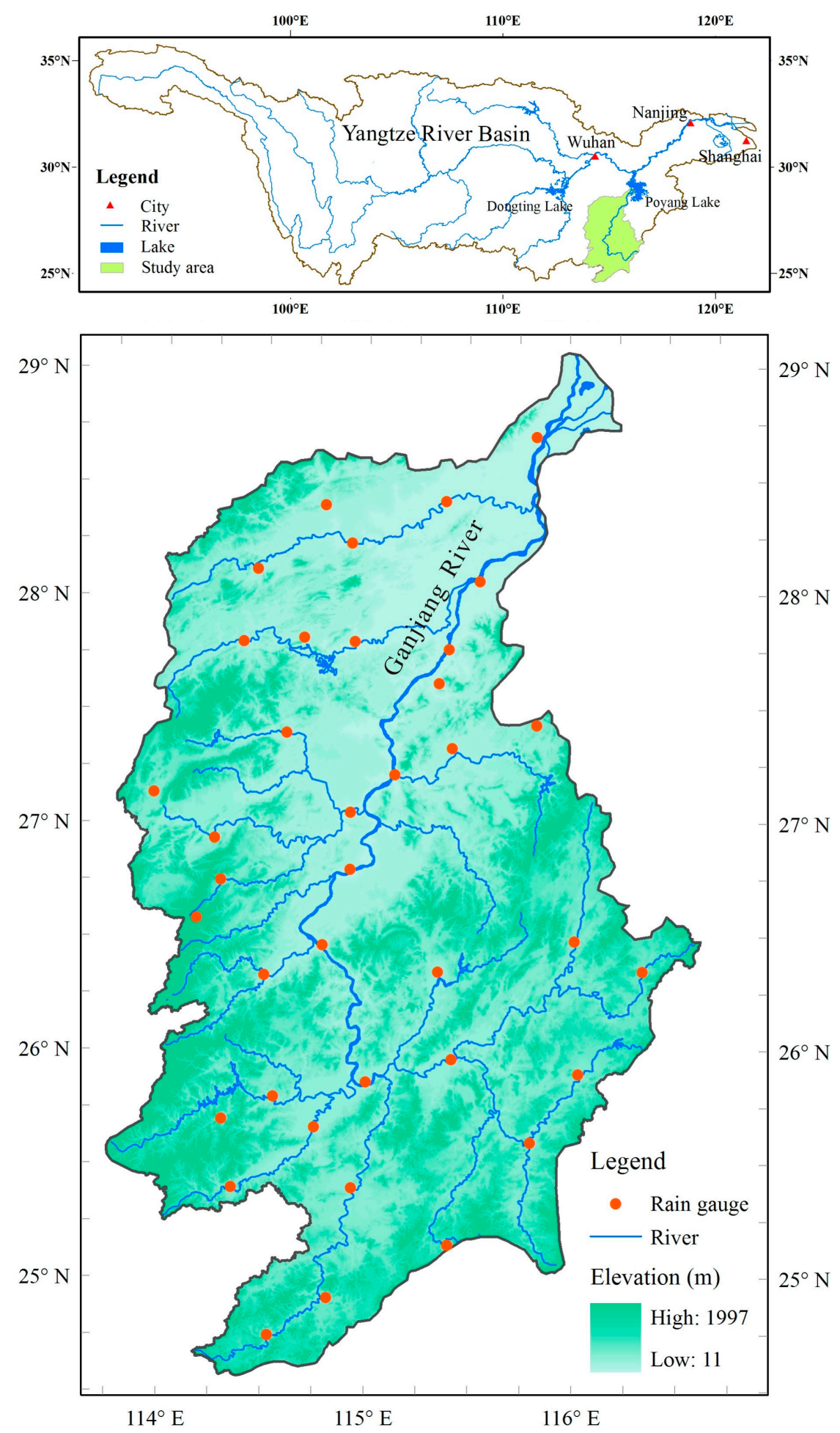

Figure 1. Location of the study area and the distribution of stations.

The Ganjiang River catchment belongs to the subtropical moist monsoon climate zone and is one of the typical rainstorm regions in China. The average annual precipitation is $1564 \mathrm{~mm}$ for the period of $1960-2012$, and the annual mean temperature is $17.5^{\circ} \mathrm{C}$. The front-type and typhoon-type rainfall events are two important phenomena in this area. Precipitation across the catchment is mainly concentrated in April-June (i.e., the rainy season), which accounts for approximately $44.3 \%$ of the annual precipitation [63]. Moreover, the maximum precipitation usually occurs in the northwest and 
east of the Ganjiang River catchment during the rainy season because of the local topography and monsoon climate. Woodland is the main land use in the Ganjiang River catchment and covers $73.0 \%$ of the catchment area, followed by cropland at $24.6 \%$ and grassland at $1.3 \%$. Other land uses, such as water bodies and built-up land, are minor, with a total area of $1.1 \%$. Soil types of the catchment are dominated by red soil $(63.9 \%)$ and paddy soil (17.8\%); other types include latosols $(9.7 \%)$, yellow soil (4.9\%), purplish soil (2.2\%), and yellow-brown soil (1.5\%) [59].

Daily precipitation data from 38 meteorological stations in the Ganjiang River catchment were collected from the National Meteorological Information Center of China for the period of 1960-2012. The locations of these stations are shown in Figure 1. This data was used in the study to estimate the rainfall erosivity and erosivity density based on an empirical equation and to detect the spatiotemporal distribution and long-term trends of rainfall erosivity. It is worth mentioning that this data has been widely used for different studies $[59,64-66]$ and that the quality of the data has been proven reliable.

\section{Methods}

\subsection{Rainfall Erosivity}

Because of the lack of long-term time series of rainfall data with high temporal resolution that can be used to calculate USLE or RUSLE rainfall erosivity, daily rainfall data has been used worldwide to estimate rainfall erosivity. In China, a daily rainfall model was proposed by Zhang et al. [24], and their results indicated that the performance of the daily rainfall model was obviously better, with an average relative error for estimating annual rainfall erosivity of only $4.2 \%$ [37]. This method was subsequently well tested and widely used in China at national and regional scales. The model is considered reliable and was applied in this study to estimate the variation of rainfall erosivity within the Ganjiang River catchment. The value of RE is calculated as:

$$
R E_{i}=\alpha \sum_{j=1}^{k}\left(P_{j}\right)^{\beta}
$$

where $R E_{i}$ is the rainfall erosivity in the $i$ th half-month $\left(\mathrm{MJ} \cdot \mathrm{mm} \cdot \mathrm{ha}^{-1} \mathrm{~h}^{-1}\right)$. Each month is separated into two half-months: days 1-15 and day 16 to the end of the month; one year is thus divided into 24 half-months. $P_{j}$ is the erosive rainfall on the $j$ th day $(\mathrm{mm}) . P_{j}$ is the actual rainfall when the actual rainfall is higher than $12 \mathrm{~mm}$; otherwise, $P_{j}$ is considered to be $0 . k$ is the number of days in the $i$ th half-month. The terms $\alpha$ and $\beta$ are empirical parameters determined by the following formulas:

$$
\begin{gathered}
\beta=0.8363+\frac{18.177}{\bar{P}_{d 12}}+\frac{24.455}{\bar{P}_{y 12}} \\
\alpha=21.586 \beta^{-7.1891}
\end{gathered}
$$

where $\bar{P}_{d 12}$ and $\bar{P}_{y 12}$ are the average daily and annual erosive rainfall for days with rainfall $>12 \mathrm{~mm}$, respectively.

In this study, the monthly rainfall erosivity values were aggregated from the half-month values, and the seasonal and annual RE values were aggregated from the monthly values.

\subsection{Erosivity Density}

The erosivity density is the ratio of rainfall erosivity to precipitation [67]; in practice, it measures the erosivity per rainfall unit (in $\mathrm{mm}$ ) and is expressed as $\mathrm{MJ} \cdot \mathrm{ha}^{-1} \mathrm{~h}^{-1}$. The equation is suitable for the calculation at a monthly or yearly scale. For each station, the ED for a given month or year $i$ is:

$$
E D_{i}=\frac{R E_{i}}{P_{i}}
$$


The erosivity density is highly reliant on rainfall intensity and influences event sediment concentration (i.e., soil loss per unit quantity of water) [15]. Large ED values suggest that rainfall occurs in the form of high intensity events (e.g., rainstorms) during the respective month or year. According to Dabney et al. [68], very high monthly erosivity density values $\left(>3 \mathrm{MJ} \cdot \mathrm{ha}^{-1} \mathrm{~h}^{-1}\right)$ significantly contribute to much higher predictions of runoff; this means that regions with high erosivity density are exposed to a risk of flooding (and even water scarcity) because of their infrequent but very intense and erosive rainstorms [15].

\subsection{Spatial Interpolation and Temporal Changes}

In this study, the spatial distribution of RE and ED was interpolated by the inverse distance weighted (IDW) technique with a power of 2. Moreover, the usual spatial distribution of the long-term average annual rainfall erosivity, which was obtained by interpolating the long-term average annual rainfall erosivity of each station, probably loses the chronological information of rainfall erosivity, which reduces the reliability of the interpolation results. We adopted the approach of Qin et al. [41] for reference: the spatial distribution of rainfall erosivity for each year was first interpolated using the IDW method; then, the spatial distribution for the entire period (1960-2012) and each decade were obtained by averaging the interpolation results of the corresponding years.

The three-year moving averages of rainfall erosivity and erosivity density were used to analyze the temporal changes because there was a three- to four-year periodicity to the change in annual precipitation [69] in most regions of China that could smooth the fluctuations and reduce the potential errors [41]. The trends of annual rainfall erosivity and erosivity density were detected with the nonparametric Mann-Kendall (M-K) test, and the trend magnitude was estimated with the nonparametric Sen's method [70]. The evaluation was based on the Excel template application MAKESENS, developed by Salmi et al. [71] for detecting trends in climatologic and hydrologic time series. The M-K test is widely used because it is simple and does not require the data to be normally distributed. In the M-K test, a positive $z$ value indicates an increasing trend and a negative value indicates a decreasing trend. The trend is statistically significant at the $0.1,0.05$, and 0.01 significance levels when $|\mathrm{z}|>1.645,1.96$, and 2.576 , respectively.

\section{Results}

\subsection{Intra-Annual Distribution of RE and ED}

The intra-annual distributions of rainfall erosivity for the Ganjiang River catchment during the study period are summarized using box plots of the mean, upper, and lower quartiles and maximum and minimum monthly RE values, as shown in Figure 2a. It is seen that the RE had a large monthly variation. With the beginning of the rainy season in the Ganjiang River catchment in April, the monthly rainfall erosivity increased quickly from January and reached its peak from April to June, then sharply decreased in July; RE became very small after September when the catchment began its dry season and lasted through December. The largest monthly RE was nearly up to $4000 \mathrm{MJ} \cdot \mathrm{mm} \cdot \mathrm{ha}^{-1} \mathrm{~h}^{-1}$ in June, with an average of $1782 \mathrm{MJ} \cdot \mathrm{mm} \cdot \mathrm{ha}^{-1} \mathrm{~h}^{-1}$, whereas the low monthly RE values were principally in the winter months, with an average of $218 \mathrm{MJ} \cdot \mathrm{mm} \cdot \mathrm{ha}^{-1} \mathrm{~h}{ }^{-1}$. Moreover, there were obvious differences in the variation characteristics of rainfall erosivity between the different decades, as shown in Figure $2 b$. The largest monthly RE varied from $1440 \mathrm{MJ} \cdot \mathrm{mm} \cdot \mathrm{ha}^{-1} \mathrm{~h}^{-1}$ in the $1980 \mathrm{~s}$ to $2210 \mathrm{MJ} \cdot \mathrm{mm} \cdot \mathrm{ha}^{-1} \mathrm{~h}^{-1}$ in the 2010s. 

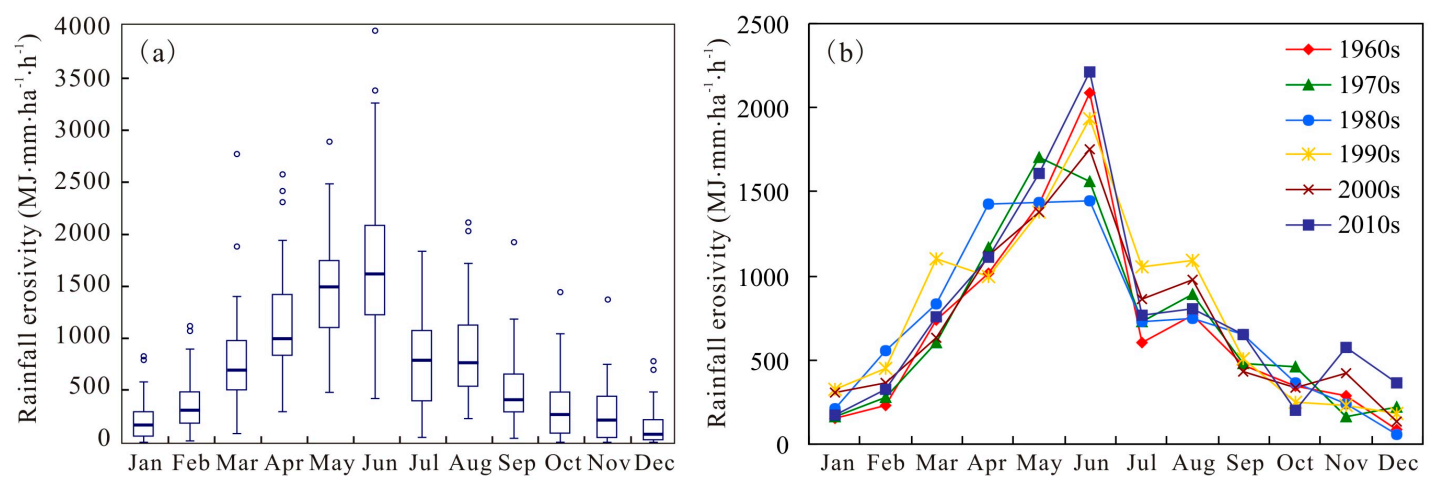

Figure 2. Intra-annual distribution of (a) monthly rainfall erosivity (b) average RE per 10 years during the period of 1960-2012.

Influenced by the monsoon climate, the rainstorms did not fall in winter and seldom occurred in autumn in the Ganjiang River catchment, and the RE had a large seasonal variation. Over $70 \%$ of the total annual RE was concentrated in spring and summer seasons. Specifically, the spring RE ranged from $1988 \mathrm{MJ} \cdot \mathrm{mm} \cdot \mathrm{ha}^{-1} \mathrm{~h}^{-1}$ in the $1960 \mathrm{~s}$ to $2814 \mathrm{MJ} \cdot \mathrm{mm} \cdot \mathrm{ha}^{-1} \mathrm{~h}^{-1}$ in the $1980 \mathrm{~s}$, which accounted for 23.0-32.4\% of the total annual RE. The largest rainfall erosivity was found in summer; it accounted for $41.6-50.1 \%$ and ranged between 3611 and $4584 \mathrm{MJ} \cdot \mathrm{mm} \cdot \mathrm{ha}^{-1} \mathrm{~h}^{-1}$. The average RE values for the autumn and winter season were only 1749 and $657 \mathrm{MJ} \cdot \mathrm{mm} \cdot \mathrm{ha}^{-1} \mathrm{~h}^{-1}$ and occupied $20.0 \%$ and $7.5 \%$ of the annual total, respectively (Table 1).

Table 1. Seasonal distribution of rainfall erosivity and its percentage in different decades.

\begin{tabular}{|c|c|c|c|c|c|c|c|c|c|c|}
\hline \multirow[b]{2}{*}{ Decades } & \multicolumn{2}{|l|}{ Spring } & \multicolumn{2}{|l|}{ Summer } & \multicolumn{2}{|l|}{ Autumn } & \multicolumn{2}{|l|}{ Winter } & \multicolumn{2}{|c|}{ Annual RE } \\
\hline & $\begin{array}{c}\text { RE } \\
(\mathrm{MJ} \cdot \mathrm{mm} / \mathrm{ha} \cdot \mathrm{h})\end{array}$ & $\begin{array}{c}P \\
(\%)\end{array}$ & $\begin{array}{c}\text { RE } \\
(\mathrm{MJ} \cdot \mathrm{mm} / \mathrm{ha} \cdot \mathrm{h})\end{array}$ & $\begin{array}{c}P \\
(\%)\end{array}$ & $\begin{array}{c}\text { RE } \\
(\mathrm{MJ} \cdot \mathrm{mm} / \mathrm{ha} \cdot \mathrm{h})\end{array}$ & $\begin{array}{c}P \\
(\%)\end{array}$ & $\begin{array}{c}\text { RE } \\
(\mathrm{MJ} \cdot \mathrm{mm} / \mathrm{ha} \cdot \mathrm{h})\end{array}$ & $\begin{array}{c}P \\
(\%)\end{array}$ & $\begin{array}{c}\text { RE } \\
(\mathrm{MJ} \cdot \mathrm{mm} / \mathrm{ha} \cdot \mathrm{h})\end{array}$ & $\begin{array}{c}P \\
(\%)\end{array}$ \\
\hline 1970 s & 2057 & 24.4 & 4004 & 47.5 & 1834 & 21.8 & 536 & 6.4 & 8431 & 100 \\
\hline 1980 s & 2814 & 32.4 & 3611 & 41.6 & 1759 & 20.3 & 498 & 5.7 & 8682 & 100 \\
\hline 1990 s & 2545 & 26.8 & 4370 & 46.0 & 1855 & 19.5 & 727 & 7.7 & 9497 & 100 \\
\hline Average & 2298 & 26.2 & 4052 & 46.3 & 1749 & 20.0 & 657 & 7.5 & 8756 & 100 \\
\hline
\end{tabular}

Notes: RE represents rainfall erosivity; P represents percentage.

Erosivity density can be used to distinguish between high rainfall erosivity values that are mainly influenced by high rainfall amounts and those influenced by rainfall of relatively low amounts but high intensity. That distinction helps to evaluate the potential consequences of rainfall erosivity for each month [72]. Each monthly RE dataset in this study was divided by the corresponding monthly precipitation dataset (according to Equation (4)), which resulted in a monthly ED dataset. Figure 3 shows the average intra-annual distribution of ED compared with the variation of RE and precipitation. ED values higher than 1 indicate that a certain precipitation amount may cause relatively higher rainfall erosivity [15]. Figure 3 shows that the erosivity density values ranged from $3.18 \mathrm{MJ} \cdot \mathrm{ha}^{-1} \mathrm{~h}^{-1}$ in December to $7.15 \mathrm{MJ} \cdot \mathrm{ha}^{-1} \mathrm{~h}^{-1}$ in June, which means that the ED value was larger than 1 in every month. High erosivity density values indicate that the precipitation was characterized by high intensity events of short duration (i.e., rainstorms), especially in June. Therefore, in terms of erosivity, June was perhaps the most dangerous month in the Ganjiang River catchment because of the largest rainfall erosivity and the highest erosivity density. 


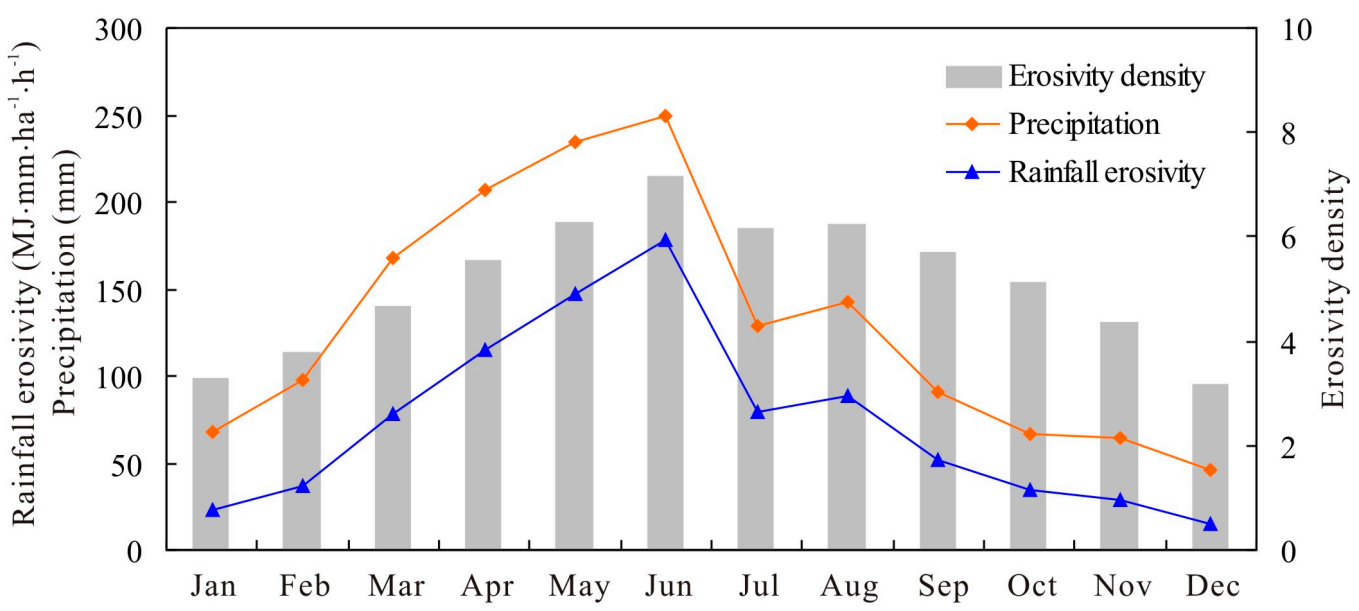

Figure 3. Variation of monthly erosivity density, rainfall erosivity, and precipitation.

\subsection{Inter-Annual Variation of RE and ED}

The inter-annual variation of RE and the corresponding M-K test trends from 1960 to 2012 are shown in Figure 4. It can be seen that the RE ranges between $4801 \mathrm{MJ} \cdot \mathrm{mm} \cdot \mathrm{ha}^{-1} \mathrm{~h}^{-1}$ in 1963 and $12,214 \mathrm{MJ} \cdot \mathrm{mm} \cdot \mathrm{ha}^{-1} \mathrm{~h}^{-1}$ in 2002 , with an average value of $8756 \mathrm{MJ} \cdot \mathrm{mm} \cdot \mathrm{ha}^{-1} \mathrm{~h}^{-1}$. The time series of RE shows a long-term increasing trend over the entire study period, and this increasing trend is displayed more clearly in the three-year moving average series, with an M-K statistic of 1.21 (Table 2), although this is not significant at the 0.05 significance level. It can also be seen from Figure $4 \mathrm{~b}$ that an abrupt change of the annual rainfall erosivity occurred in the 1970s and, after that, the annual RE increased continuously. Figure 4 indicates that the risk of erosive rainfall and soil erosion in the Ganjiang River catchment is becoming more and more serious.
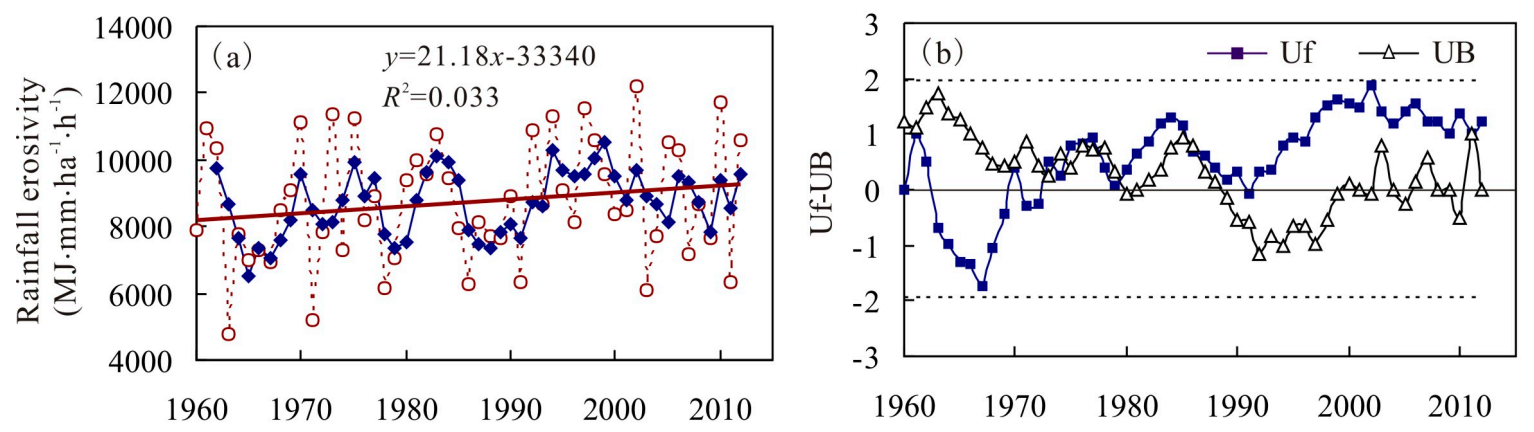

Figure 4. Variation of (a) annual rainfall erosivity and (b) the corresponding Mann-Kendall (M-K) test trends during the period of 1960-2012 (the line with the solid dots in (a) marks the three-year moving average and the horizontal dashed lines in (b) represent the critical value of the 0.05 significance level).

However, the trends presented different significances for the different seasons, as shown in Figure 5. Although the slight increasing trends are found in the first three seasons, with M-K statistics of $0.64,0.68$, and 0.35 , respectively (Table 2 ) (also not significant), the three-year moving average shows an obvious decreasing trend since the early 1980s for spring and since the early 2000s for autumn. For winter, a significant increasing trend (at the 0.05 significance level) is observed, with an M-K statistic of 2.13 (Table 2). The RE increased obviously after the end of the 1980s. Figure 5 indicates that the risk of soil erosion in winter was becoming increasingly higher in the Ganjiang River catchment, although the rainfall erosivity in winter only occupied a small percentage. 

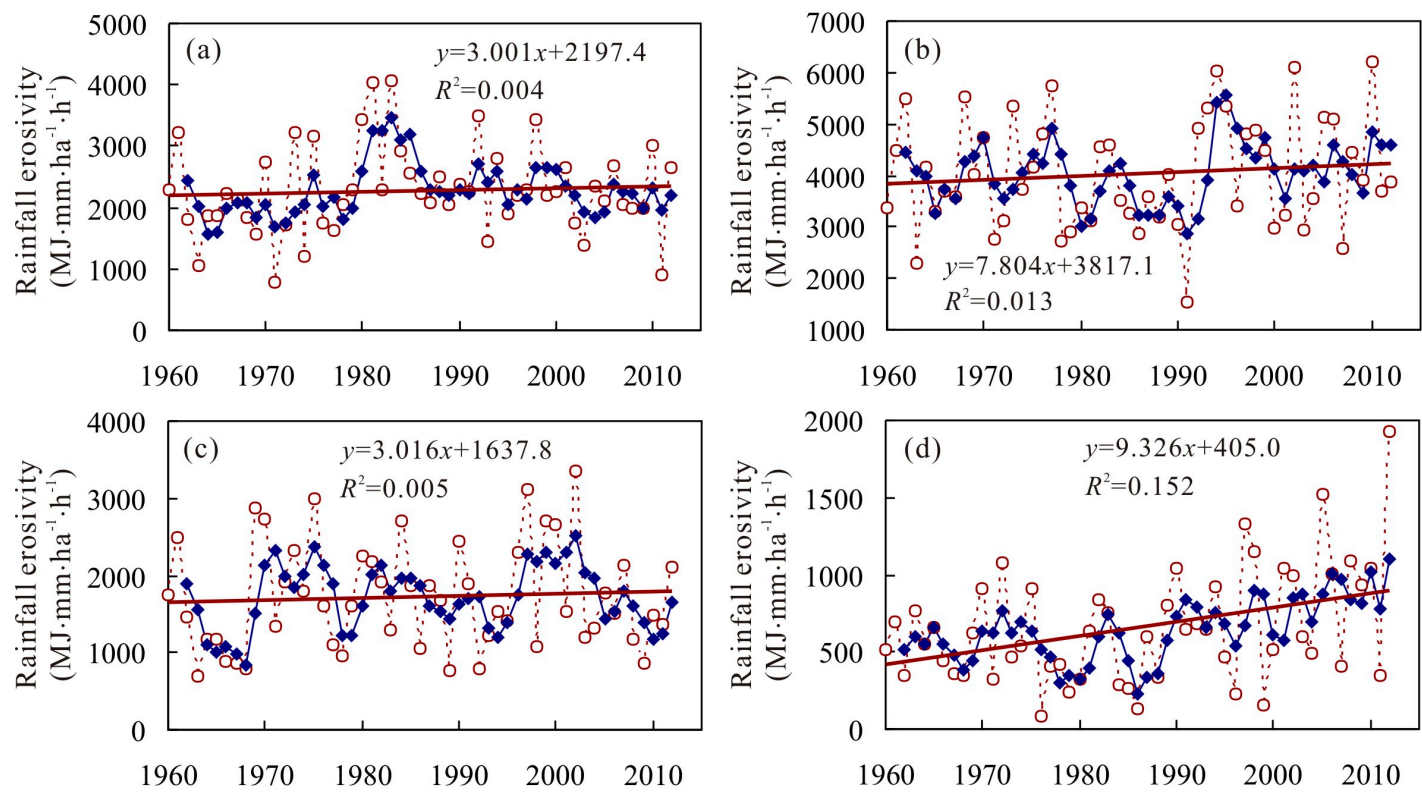

Figure 5. Variation of seasonal rainfall erosivity for (a) spring, (b) summer, (c) autumn, and (d) winter during the period of 1960-2012.

Table 2. Results of the M-K test for seasonal and annual RE and annual erosivity density (ED).

\begin{tabular}{ccccccc}
\hline & Spring & Summer & Autumn & Winter & Annual RE & Annual ED \\
\hline M-K statistic & 0.64 & 0.68 & 0.35 & $2.13 *$ & 1.21 & $2.500^{*}$ \\
\hline \multicolumn{7}{c}{ Notes: ${ }^{*}$ indicates that the value exceeded the 0.05 significance level. }
\end{tabular}

Figure 6 shows the variation of ED and the corresponding M-K test trends during the period of 1960-2012. It was found that the annual ED had a high year-to-year variability, which ranges from $4.48 \mathrm{MJ} \cdot \mathrm{ha}^{-1} \mathrm{~h}^{-1}$ in 1963 to $6.34 \mathrm{MJ} \cdot \mathrm{ha}^{-1} \mathrm{~h}^{-1}$ in 2005 , with the mean value of $5.44 \mathrm{MJ} \cdot \mathrm{ha}^{-1} \mathrm{~h}^{-1}$. The annual ED showed a significant long-term increasing trend $(\alpha=0.05)$ over the entire period, with an M-K statistic of 2.50 (Table 2). At the same time, Figure $6 \mathrm{~b}$ shows that an abrupt change of the ED occurred in 1990, and after that, the annual ED increased more clearly. Specifically, the increasing trend was significant after 2000 at the significance level $(\alpha=0.05)$ as the values of Uf are above the critical values. Because the ED values are directly proportional to the rainfall intensity, this can reflect the variation of rainfall intensity at a location. Figure 6 contributed to identifying the regional trends of rainfall intensity and possible signals of climate change in the Ganjiang River catchment, which implies that the catchment may suffer increasingly serious soil erosion.
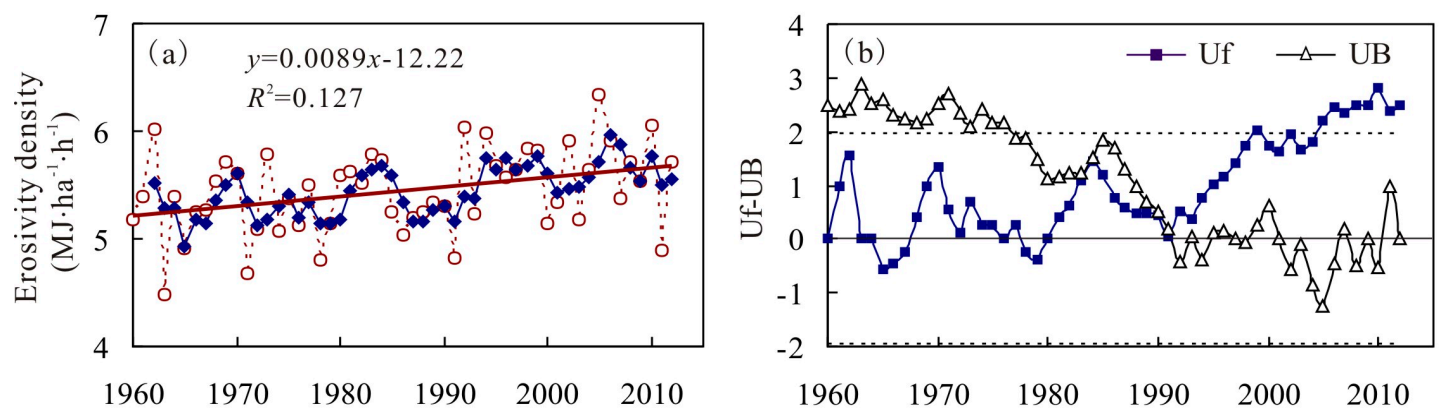

Figure 6. Variation of (a) erosivity density and (b) the corresponding M-K test trends during the period of 1960-2012 (the line with the solid dots in (a) marks the three-year moving average and the horizontal dashed lines in (b) represent the critical value of the 0.05 significance level). 


\subsection{Spatial Distribution of RE and ED}

The 12 maps of monthly rainfall erosivity in the Ganjiang River catchment are shown in Figure 7, which demonstrates a clear spatial heterogeneity. It can be seen that the largest monthly RE values are observed in May and June, which are also the months with remarkable spatial variation. The RE values in the eastern and northeast parts of the catchment are larger than those in the western part, with a monthly RE gradient of more than $800 \mathrm{MJ} \cdot \mathrm{mm} \cdot \mathrm{ha}^{-1} \mathrm{~h}^{-1}$. Nonetheless, the lowest monthly RE values are observed in December and January and the gradient of RE is small (less than $100 \mathrm{MJ} \cdot \mathrm{mm} \cdot \mathrm{ha}^{-1} \mathrm{~h}^{-1}$ ), although the spatial distribution is also uneven from the middle parts to the northern or southern parts of the catchment in these months (Figure 7). In spring, the monthly RE values in the eastern part are relatively higher than those in the western part, whereas the RE values in the southern part are higher than those in other regions in autumn (Figure 7). The general spatial patterns of rainfall erosivity in the monthly maps exhibit a smooth increase of RE from winter to spring, followed by a sharp intensification in the summer and a smooth decrease in autumn. This general pattern of monthly RE is also in accordance with the spatial variability of rainfall intensity in the Ganjiang River catchment.

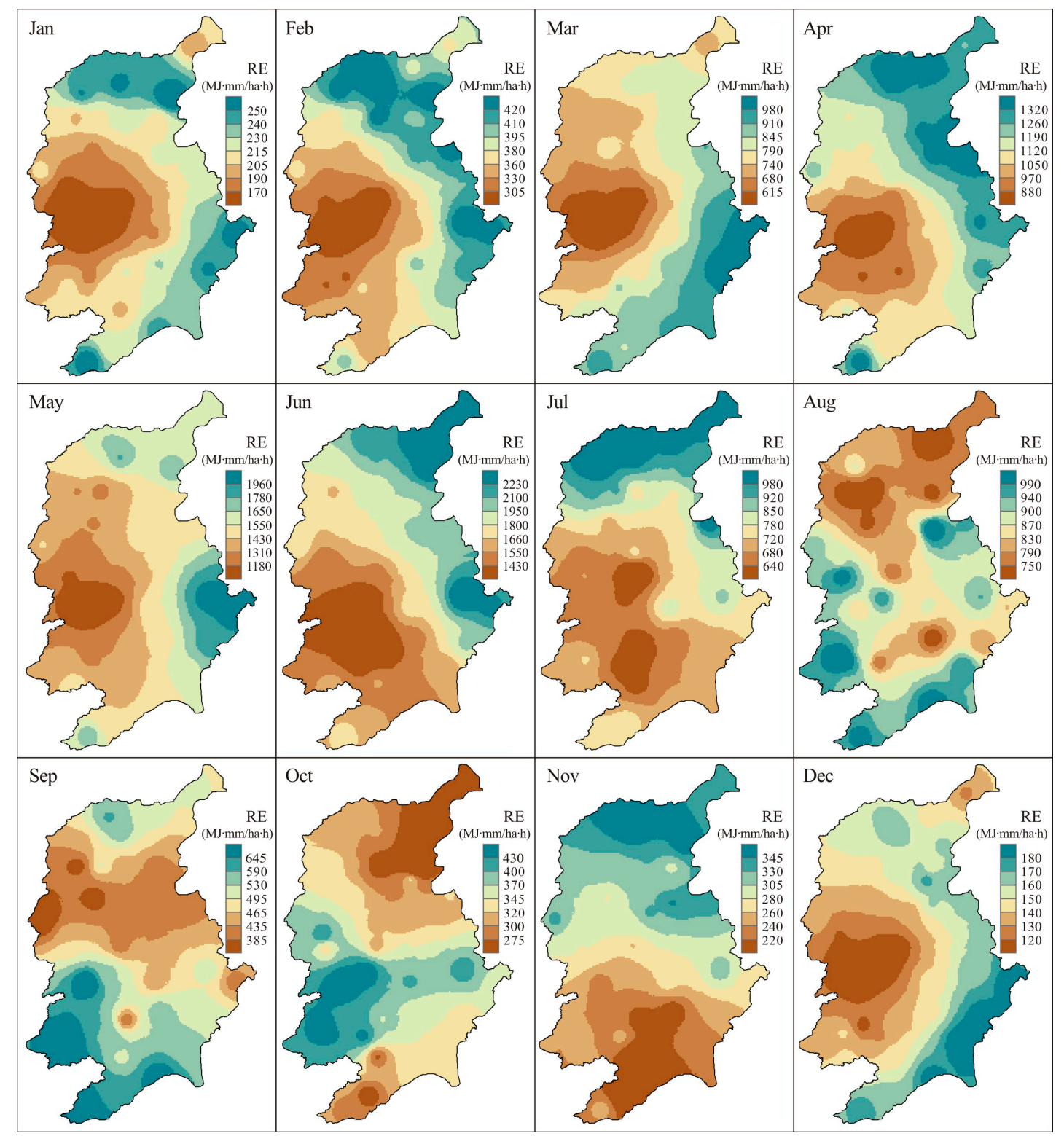

Figure 7. Spatial distribution of monthly rainfall erosivity in the Ganjiang River catchment. 
The spatial distribution of the annual RE in the Ganjiang River catchment is aggregated from the monthly maps in each decade, and the comparison with the spatial distribution of annual erosive rainfall is shown in Figure 8. It can be seen that the spatial distribution of the annual RE shows a strong variability trend. The highest annual $\mathrm{RE}$ values (more than $11,000 \mathrm{MJ} \cdot \mathrm{mm} \cdot \mathrm{ha}^{-1} \mathrm{~h}^{-1}$ ) are found in the eastern and northeast parts of the catchment, and the lowest annual RE values (less than $7200 \mathrm{MJ} \cdot \mathrm{mm} \cdot \mathrm{ha}^{-1} \mathrm{~h}^{-1}$ ) are consistently distributed in the western high mountainous and hilly areas. These spatial patterns of RE are highly consistent with the spatial distribution of the annual erosive rainfall (Figure 8a). Figure 8c displays the spatial distribution of annual ED over the Ganjiang River catchment. It can be seen that the annual ED is similar to the annual RE and has a strong spatial variability. The highest annual ED values are concentrated in the eastern and northeast parts of the catchment, whereas the lowest values are mainly found in the western parts, especially in the high mountainous and hilly areas. Regions of high erosivity density indicate a higher risk of erosive rainstorms and, thus, high soil erosion and flooding $[15,68]$. Figure 8 further reveals that the spatial distributions of annual RE and ED are strongly influenced by the spatial variability of annual erosive rainfall. Moreover, the eastern and northeast parts of the catchment are exposed to a high risk of flooding due to their strong erosive rainstorms, as well as the high rainfall erosivity and erosivity density in these parts.
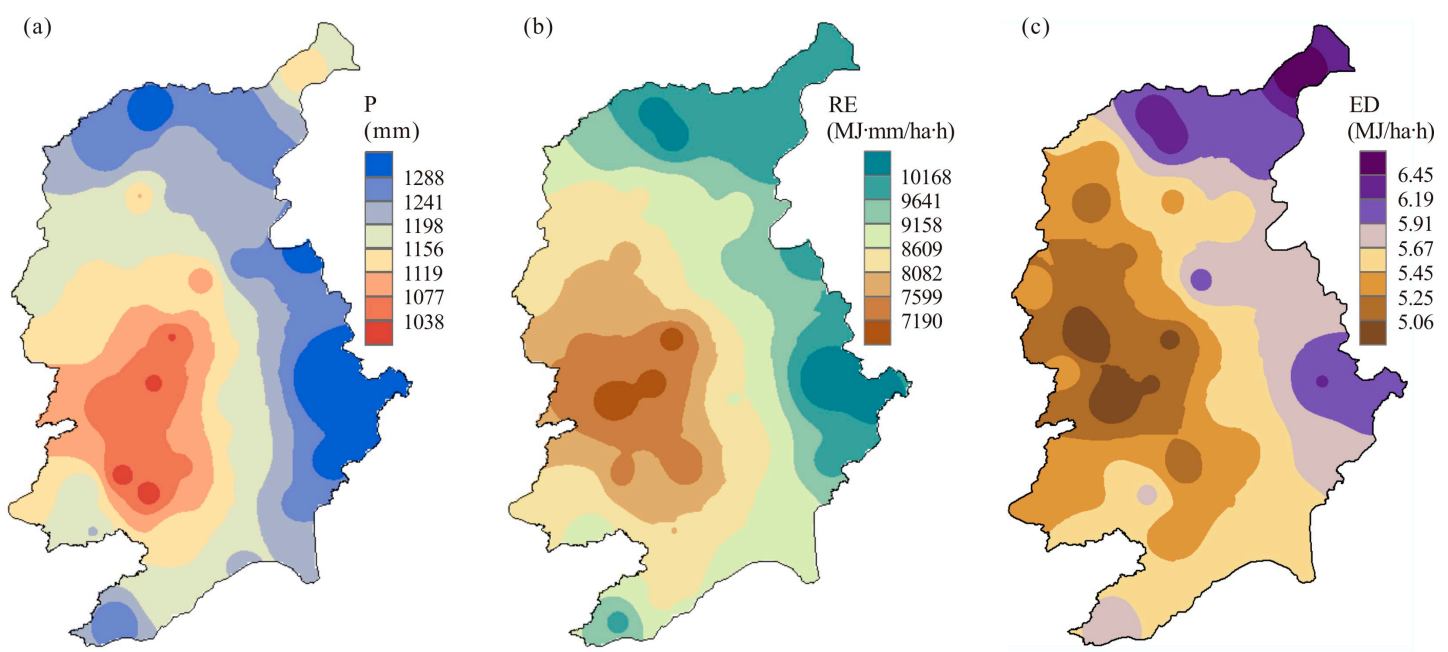

Figure 8. Comparison of spatial distribution of (a) annual erosive rainfall, (b) annual rainfall erosivity, and (c) erosivity density in the Ganjiang River catchment.

The long-term trends of the annual RE and ED for each meteorological station in the Ganjiang River catchment are examined with the M-K test method, and the results are shown in Figure 9. It can be seen that the RE has increased at 36 (94.7\%) of the 38 stations from 1960 to 2012, and four (10.5\%) of these are statistically significant at the 0.1 significance level. The stations with decreasing trends are mainly located in the high mountainous and hilly areas. A similar spatial pattern is also found for the ED, but more stations present statistically significant increasing trends at the 0.1 significance level, and three of them even exceed the 0.05 significance level. Figure 9 indicates that the potential of soil erosion caused by erosive rainfall was intensified during the period of 1960-2012, and the soil erosion conditions in the Ganjiang River catchment are becoming aggravated, especially in the northeastern and eastern areas. 

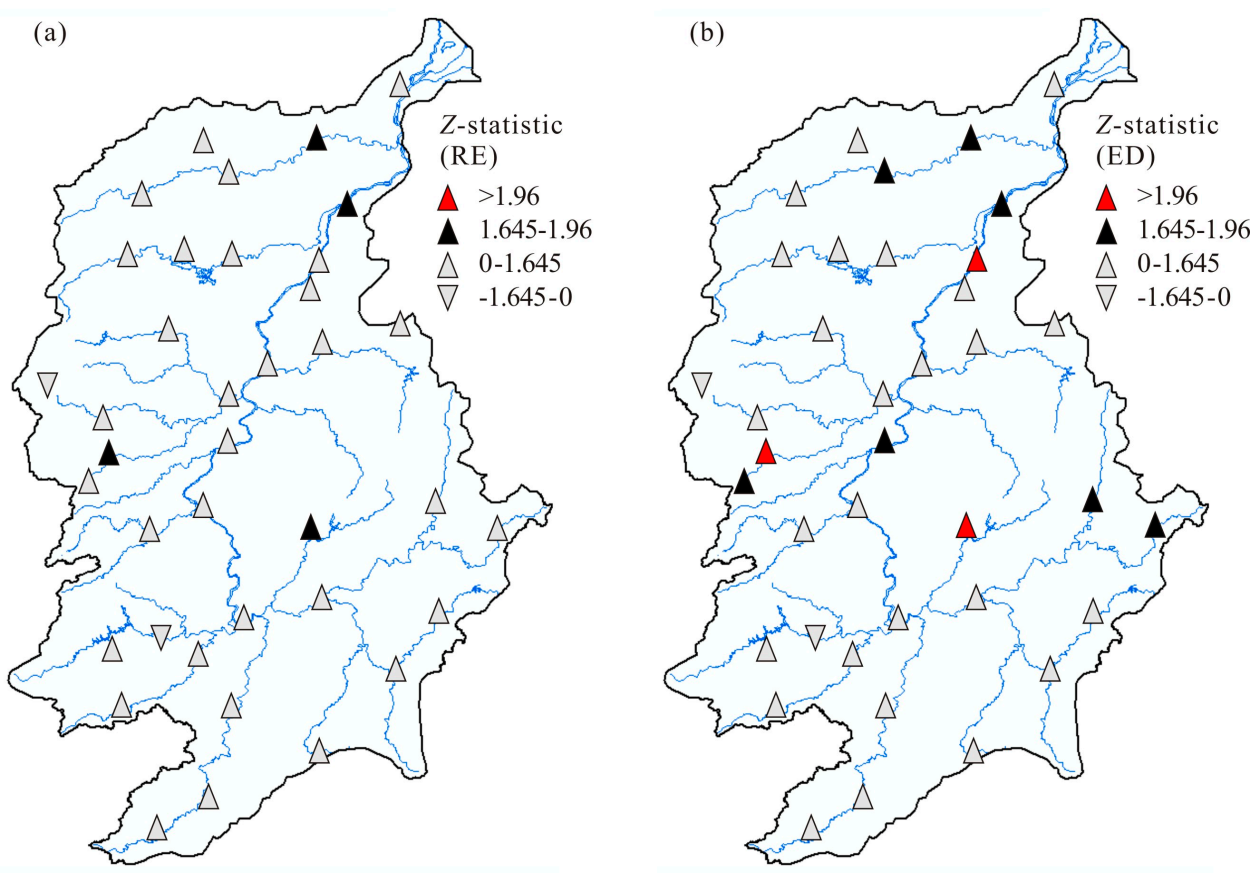

Figure 9. Spatial patterns of the long-term trends of (a) annual rainfall erosivity and (b) erosivity density.

In addition, it is important to note that the wide alluvial plains surrounding Poyang Lake and the broad alluvial valleys in the lower reaches of the primary tributary are important rice growing regions in Jiangxi Province, as well as in China [59]. The soil erosion and land degradation in this area may cause more serious damage to the development of society, the economy, and agricultural production. Therefore, the lower reaches of the Ganjiang River catchment is an area of higher risk and more attention should be paid to soil erosion caused by rainfall in this area.

\section{Discussion}

The previous sections presented the spatiotemporal distribution characteristics of rainfall erosivity and erosivity density in the Ganjiang River catchment. The estimation reveals that the rainfall erosivity shows a high year-to-year variability. The annual RE ranges between 4801 and $12,214 \mathrm{MJ} \cdot \mathrm{mm} \cdot \mathrm{ha}^{-1} \mathrm{~h}^{-1}$, with an average value of $8756 \mathrm{MJ} \cdot \mathrm{mm} \cdot \mathrm{ha}^{-1} \mathrm{~h}^{-1}$. Almost half of the annual RE was found in the summer. Li et al. [73] also estimated the amount of annual rainfall erosivity in the Liao catchment, a catchment adjacent to the Ganjiang River catchment, and found that the average annual RE was $8055 \mathrm{MJ} \cdot \mathrm{mm} \cdot \mathrm{ha}^{-1} \mathrm{~h}^{-1}$; the lowest value of $5733 \mathrm{MJ} \cdot \mathrm{mm} \cdot \mathrm{ha}^{-1} \mathrm{~h}^{-1}$ was at Jiujiang station and the highest value of $12,628 \mathrm{MJ} \cdot \mathrm{mm} \cdot \mathrm{ha}^{-1} \mathrm{~h}^{-1}$ was at Lushan station. They further pointed out that most of the erosion occurred in May, June, and July; largely during some major storms. These findings agree with the findings of the current study, except for a slightly smaller average annual RE. The possible causes for this difference between the results include the different climate characteristics in the two catchments and different values of coefficients in the calculation equation of RE. Qin et al. [41] revealed that the average annual RE was $9480 \mathrm{MJ} \cdot \mathrm{mm} \cdot \mathrm{ha}^{-1} \mathrm{~h}^{-1}$ in the southern red soil hilly region of China (including the Poyang Lake basin) during the period of 1951-2010; this is approximately two times higher than that of the southwest purple soil region and the southwest Karst region, both located in south China. This higher estimation of annual RE compared to that of the current study can be attributed to the more extensive area with severe soil erosion. The temporal trend analysis reveals that the annual rainfall erosivity and erosivity density present long-term increasing trends over the entire study period, although the trends are not significant at the 0.05 significance level. Similarly, significant increasing trends (at the 0.05 level) were found in the southern red soil hilly region at a national scale 
in the study of Qin et al. [41]. The increasing trends indicate that the soil erosion conditions in the Ganjiang River catchment, as well as other red soil hilly regions, are becoming aggravated. Similar findings can also be found in the study of Xie et al. [47]. At the decadal scale, Qin et al. [41] revealed that the decadal rainfall erosivity has shown an increasing trend since the 1960s, peaking in the 1990s; then, the decadal RE decreased in the 2000s. A similar changing characteristic is also presented in this study. High consistency with other studies indicates that the method used in this study (based on daily rainfall series) is reliable. This is further validated by the works Xie et al. [47] and Yin et al. [48], who calibrated and compared models suitable for estimating erosivity from daily rainfall data.

The changing climate could be a strong factor influencing the trends and variability of rainfall erosivity and erosivity density in time and space. Precipitation is a primary driving factor of soil erosion; its intensity, amount, duration, timing, and rate directly affect the spatiotemporal distribution of RE and ED. The effect of climate change on soil erosion was observed by Routschek et al. [74] to be due to changes in the rainfall. A study also shows that the increased intensity of various climatic parameters, particularly rainfall, has caused an increase in the sediment load [75]. Figure 10 shows the scatter plots of annual rainfall erosivity and erosivity density against rainfall over the Ganjiang River catchment. It can be seen that the annual RE shows a good linear relationship with the precipitation, and the determination coefficient $\left(R^{2}\right)$ is 0.88 for the annual total rainfall and as high as 0.93 for the annual erosive rainfall. The ED also presents a good linear relationship, with an $R^{2}$ of 0.66 for the annual total rainfall and 0.73 for the annual erosive rainfall. High $R^{2}$ values further indicate that the variations of annual RE and ED are principally associated with the precipitation in the catchment. The spatiotemporal distribution characteristics of precipitation in the Poyang Lake basin are strongly influenced by the East Asian summer monsoon (EASM). A larger amount of atmospheric moisture is transported from the East or South China Sea by the EASM every year [76]. Generally, the rainy season in the catchment is from April to June. The rainfall in the rainy season accounts for nearly $50 \%$ of the total annual rainfall. Moreover, almost all extreme precipitation events occurred in this period. From July to August, the precipitation decreases sharply and, after that, the catchment enters its dry season, which lasts through December [59]. The intra-annual distribution patterns of the RE and ED in the Ganjiang River catchment (e.g., the largest seasonal RE and ED are found in the summer) are mainly dependent on the annual distribution of precipitation in the catchment. With regard to space, the variability in EASM limits its northward extension and keeps a longer rainy season in southern China. This position favors a steady increase in not only the total rainfall but also the extreme precipitation events in the Poyang Lake basin during the summer [77-79]. The northeastern part of the catchment is an area with strong rainfall. Therefore, the strong influence of EASM is mainly responsible for the temporal and spatial distribution of RE and ED in the study area.
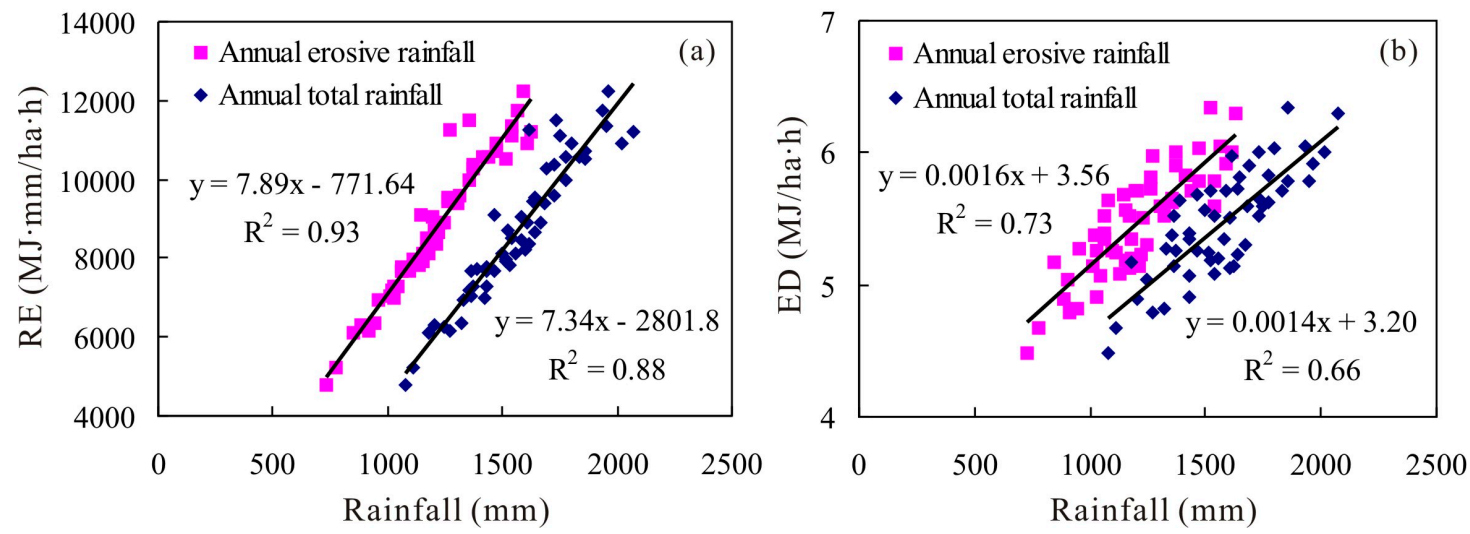

Figure 10. Scatter plots of precipitation and (a) annual rainfall erosivity and (b) erosivity density. 
The temperature is another critical component to depict climate changes. Generally, higher temperatures may trigger heavy and extreme precipitation more easily; this is directly related to the strong rainfall erosivity and erosivity density. According to the analyses of Ye et al. [80] and Zhang et al. [81], the mean temperature in the Poyang Lake basin shows a long-term increasing trend (at a rate of $0.1-0.16^{\circ} \mathrm{C}$ per decade) due to the intensified global warming and rapid development of local industry in the last five decades. This increase in temperature undoubtedly improves the ability of the atmosphere to hold more water as described by the Clausius-Clapeyron relationship [82] and, furthermore, causes heavier precipitation. This is consistent with expected impacts of climate change on precipitation. Zhang et al. [83] reported that the intensifying heavy and extreme precipitation occurred mainly in the north of the Poyang Lake basin, where areas are dominated by increasing temperatures. Other research also revealed that heavy and extreme precipitation was intensified in the Poyang Lake basin during last six decades [51,76,83]. The increasing trend was especially significant before the year 2000, and the extreme precipitation played an increasingly important role in contributing to the annual rainfall. The changes in climate may help explain why the risk of erosive rainfall and soil erosion in the Ganjiang River catchment is becoming more and more serious.

Finally, it is also important to recognize that, although the method used in this study has its inherent advantages in depicting the changing characteristics of rainfall erosivity and erosivity density in the Ganjiang River catchment, several uncertainties still exist regarding the application of the method. For example, $\alpha$ and $\beta$ are important weight coefficients in the calculation equation of RE and their values are related to the time scale of study, as well as the zonal climate characteristics [24]. Values are directly adopted in this study according to the previous studies of Zhang et al. [24], Zhang and Fu [37], Xie et al. [47], and Gu et al. [10] in other Chinese catchments. Richardson et al. [84] even suggested that the $\alpha$ value should be different between the warm season and cool season; this is because the same amount of rainfall in the warm season can generate a higher erosivity than that in the cool season, because the summer rains tended to be more intense than winter rains. Additionally, strong year-to-year variability and spatial distribution of erosivity density were observed during the study period. Panagos et al. [15,43] considered that the high spatial and temporal variability of ED highlighted the fact that rainfall erosivity is not solely dependent on the amount of precipitation. According to its definition, rainfall erosivity is directly related to the rainfall's kinetic energy and intensity. In this study, rainfall erosivity is calculated from the daily erosive rainfall, which is classified according to whether the actual daily rainfall is higher than $12 \mathrm{~mm}$ or not; this may also have introduced uncertainties into the estimation of RE. Future studies would be enhanced by investigating the relationship of parameters $\alpha$ and $\beta$ and the climate and catchment characteristics to reduce or eliminate parameter value uncertainties. Moreover, it is necessary to take more factors into account when estimating RE in future studies.

\section{Conclusions}

This study demonstrated that the rainfall erosivity in the Ganjiang River catchment showed great monthly and seasonal variation. The largest monthly RE was nearly $4000 \mathrm{MJ} \cdot \mathrm{mm} \cdot \mathrm{ha}^{-1} \mathrm{~h}^{-1}$ in June, with an average of $1782 \mathrm{MJ} \cdot \mathrm{mm} \cdot \mathrm{ha}^{-1} \mathrm{~h}^{-1}$. The lowest RE occurred in December, with an average of $218 \mathrm{MJ} \cdot \mathrm{mm} \cdot \mathrm{ha}^{-1} \mathrm{~h}^{-1}$. Moreover, over $70 \%$ of the total annual RE was concentrated in the spring and summer seasons, and ranged from 1988 to $2814 \mathrm{MJ} \cdot \mathrm{mm} \cdot \mathrm{ha}^{-1} \mathrm{~h}^{-1}$ in spring and 3611 to $4584 \mathrm{MJ} \cdot \mathrm{mm} \cdot \mathrm{ha}^{-1} \mathrm{~h}^{-1}$ in summer. The average REs for the autumn and winter seasons were only 1749 and $657 \mathrm{MJ} \cdot \mathrm{mm} \cdot \mathrm{ha}^{-1} \mathrm{~h}^{-1}$ and accounted for $20.0 \%$ and $7.5 \%$ of the total annual RE, respectively. Monthly values of erosivity density ranged from $3.18 \mathrm{MJ} \cdot \mathrm{ha}^{-1} \mathrm{~h}^{-1}$ in December to $7.15 \mathrm{MJ} \cdot \mathrm{ha}^{-1} \mathrm{~h}^{-1}$ in June. High ED values indicated that the precipitation was characterized by high intensity events of short duration (i.e., rainstorms), especially in June.

The annual RE and ED also presented high year-to-year variability. The average annual RE was $8756 \mathrm{MJ} \cdot \mathrm{mm} \cdot \mathrm{ha}^{-1} \mathrm{~h}^{-1}$, with the lowest value of $4801 \mathrm{MJ} \cdot \mathrm{mm} \cdot \mathrm{ha}^{-1} \mathrm{~h}^{-1}$ in 1963 and the highest value of $12,214 \mathrm{MJ} \cdot \mathrm{mm} \cdot \mathrm{ha}^{-1} \mathrm{~h}^{-1}$ in 2002 . The annual RE showed a long-term increasing trend over the entire 
study period, with an M-K statistic of 1.21. The annual ED ranged from $4.48 \mathrm{MJ} \cdot \mathrm{ha}^{-1} \mathrm{~h}^{-1}$ in 1963 to $6.34 \mathrm{MJ} \cdot \mathrm{ha}^{-1} \mathrm{~h}^{-1}$ in 2005. A significant increasing trend $(\alpha=0.05)$ was observed over the entire period, with an M-K statistic of 2.50. The spatial distribution of the annual RE and ED showed a strong variability trend in the eastern and northeast parts of the catchment, which had greater RE and ED values compared the western parts; the RE ranged from more than $12,000 \mathrm{MJ} \cdot \mathrm{mm} \cdot \mathrm{ha}^{-1} \mathrm{~h}^{-1}$ in the eastern part to less than $7200 \mathrm{MJ} \cdot \mathrm{mm} \cdot \mathrm{ha}^{-1} \mathrm{~h}^{-1}$ in the western part, and the ED ranged from higher than $6.45 \mathrm{MJ} \cdot \mathrm{ha}^{-1} \mathrm{~h}^{-1}$ in the eastern part to lower than $5.06 \mathrm{MJ} \cdot \mathrm{ha}^{-1} \mathrm{~h}^{-1}$ in the western part. The alluvial plains in the lower reaches of the Ganjiang River (i.e., the northern parts of the catchment) were exposed to high risks of flooding and soil erosion because of the high RE and ED values as well as the significant increasing trends in this area.

Acknowledgments: This work was jointly funded by the National Natural Science Foundation of China (41571023) and the Natural Science Foundation of Jiangxi Province (20161BAB203103).

Author Contributions: Xianghu Li conceived and designed the experiments, and wrote the manuscript; Xuchun Ye analyzed the data and improved the manuscript.

Conflicts of Interest: The authors declare no conflict of interest. The founding sponsors had no role in the design of the study; in the collection, analyses, or interpretation of data; in the writing of the manuscript, and in the decision to publish the results.

\section{References}

1. Bahadur, K.C.K. Mapping soil erosion susceptibility using remote sensing and GIS: A case of the Upper Nam Wa Watershed, Nan Province, Thailand. Environ. Geol. 2009, 57, 695-705. [CrossRef]

2. Chaplot, V. Impact of terrain attributes, parent material and soil types on gully erosion. Geomorphology 2013, 186, 1-11. [CrossRef]

3. Van Oost, K.; Quine, T.A.; Govers, G.; De Gryze, S.; Six, J.; Harden, J.W.; Ritchie, J.C.; McCarty, G.W.; Heckrath, G.; Kosmas, C.; et al. The impact of agricultural soil erosion on the global carbon cycle. Science 2007, 318, 626-629. [CrossRef] [PubMed]

4. Quinton, J.N.; Govers, G.; Van Oost, K.; Bardgett, R.D. The impact of agricultural soil erosion on biogeochemical cycling. Nat. Geosci. 2010, 3, 311-314. [CrossRef]

5. Pimentel, D. Soil erosion: A food and environmental threat. Environ. Dev. Sustain. 2006, 8, 119-137. [CrossRef]

6. Mondal, A.; Khare, D.; Kundu, S.; Mukherjee, S.; Mukhopadhyay, A.; Mondal, S. Uncertainty of soil erosion modelling using open source high resolution and aggregated DEMs. Geosci. Front. 2017, 8, 425-436. [CrossRef]

7. Oliveira, P.T.S.; Wendland, E.; Nearing, M.A. Rainfall erosivity in Brazil: A review. Catena 2013, 100, $139-147$. [CrossRef]

8. Liu, B.Y.; Bi, X.G.; Fu, S.H. Beijing Soil Loss Equation; Science Press: Beijing, China, 2010. (In Chinese)

9. Liu, Y.; Zhao, E.X.; Huang, W.; Zhou, J.Q.; Ju, J.H. Characteristic analysis of precipitation and temperature trend in Yunnan Province in recent 46 years. J. Catastrophol. 2010b, 25, 39-44. (In Chinese)

10. Gu, Z.J.; Duan, X.W.; Liu, B.; Hu, J.M.; He, J.N. The spatial distribution and temporal variation of rainfall erosivity in the Yunnan Plateau, Southwest China: 1960-2012. Catena 2016, 145, 291-300.

11. Wischmeier, W.H.; Smith, D.D. Predicting Rainfall Erosion Losses: A Guide to Conservation Planning; Agriculture Handbook No. 537; U.S. Department of Agriculture: Washington, DC, USA, 1978.

12. Renard, K.G.; Foster, G.R.; Weesies, G.A.; McCool, D.K.; Yoder, D.C. Predicting Soil Erosion by Water: A Guide to Conservation Planning with the Revised Universal Soil Loss Equation (RUSLE); Agriculture Handbook, No. 703; U.S. Departement of Agriculture: Washington, DC, USA, 1997.

13. Wang, Y.S.; Tan, S.; Liu, B.Y.; Yang, Y. Estimating rainfall erosivity by incorporating seasonal variations in parameters into the Richardson model. J. Geogr. Sci. 2017, 27, 275-296. [CrossRef]

14. Wu, L.; Liu, X.; Ma, X.Y. Spatiotemporal distribution of rainfall erosivity in the Yanhe River watershed of hilly and gully region, Chinese Loess Plateau. Environ. Earth Sci. 2016, 75, 315. [CrossRef]

15. Panagos, P.; Ballabio, C.; Borrelli, P.; Meusburger, K. Spatio-temporal analysis of rainfall erosivity and erosivity density in Greece. Catena 2016, 137, 161-172. [CrossRef] 
16. Hoyos, N.; Waylen, P.R.; Jaramillo, A. Seasonal and spatial patterns of erosivity in a tropical watershed of the Colombian Andes. J. Hydrol. 2005, 314, 177-191. [CrossRef]

17. Meshesha, D.T.; Tsunekawa, A.; Tsubo, M.; Haregeweyn, N.; Adgo, E. Evaluating spatial and temporal variations of rainfall erosivity, case of central rift valley of Ethiopia. Theor. Appl. Climatol. 2015, 119, 515-522. [CrossRef]

18. Yue, B.J.; Shi, Z.H.; Fang, N.F. Evaluation of rainfall erosivity and its temporal variation in the Yanhe River catchment of the Chinese Loess Plateau. Nat. Hazards 2014, 74, 585-602. [CrossRef]

19. Diodato, N.; Borrelli, P.; Fiener, P.; Bellocchi, G.; Romano, N. Discovering historical rainfall erosivity with a parsimonious approach: A case study in Western Germany. J. Hydrol. 2017, 544, 1-9. [CrossRef]

20. Meusburger, K.; Steel, A.; Panagos, P.; Montanarella, L.; Alewell, C. Spatial and temporal variability of rainfall erosivity factor for Switzerland. Hydrol. Earth Syst. Sci. 2012, 16, 167-177. [CrossRef]

21. Da Silva, A.M. Rainfall erosivity map for Brazil. Catena 2004, 57, 251-259. [CrossRef]

22. Lee, J.H.; Heo, J.H. Evaluation of estimation methods for rainfall erosivity based on annual precipitation in Korea. J. Hydrol. 2011, 409, 30-48. [CrossRef]

23. Loureiro, N.D.; Coutinho, M.D. A new procedure to estimate the RUSLE $\mathrm{EI}_{30}$ index, based on monthly rainfall data and applied to the Algarve Region, Portugal. J. Hydrol. 2001, 250, 12-18. [CrossRef]

24. Zhang, W.B.; Xie, Y.; Liu, B.Y. Rainfall erosivity estimation using daily rainfall amounts. Sci. Geogr. Sin. 2002, 22, 705-711. (In Chinese)

25. Diodato, N. Estimating RUSLE's rainfall factor in the part of Italy with a Mediterranean rainfall regime. Hydrol. Earth Syst. Sci. 2004, 8, 103-107. [CrossRef]

26. Diodato, N.; Bellocchi, G. Estimating monthly (R)USLE climate input in a Mediterranean region using limited data. J. Hydrol. 2007, 345, 224-236. [CrossRef]

27. Yin, S.; Xie, Y.; Nearing, M.A.; Wang, C. Estimation of rainfall erosivity using 5-to 60-minute fixed-interval rainfall data from China. Catena 2007, 70, 306-312. [CrossRef]

28. Pan, J.H.; Wen, Y. Estimation of soil erosion using RUSLE in Caijiamiao watershed, China. Nat. Hazards 2014, 71, 2187-2205. [CrossRef]

29. Cohen, M.J.; Shepherd, K.D.; Walsh, M.G. Empirical reformulation of the universal soil loss equation for erosion risk assessment in a tropical watershed. Geoderma 2005, 124, 235-252. [CrossRef]

30. De Luis, M.; Brunetti, M.; Gonzalez-Hidalgo, J.C.; Longares, L.A.; Martin-Vide, J. Changes in seasonal precipitation in the Iberian peninsula during 1946-2005. Glob. Planet Chang. 2010, 74, 27-33. [CrossRef]

31. Yang, D.W.; Kanae, S.; Oki, T.; Koike, T.; Musiake, K. Global potential soil erosion with reference to land use and climate changes. Hydrol. Process. 2003, 17, 2913-2928. [CrossRef]

32. Beskow, S.; Mello, C.R.; Norton, L.D.; Curi, N.; Viola, M.R.; Avanzi, J.C. Soil erosion prediction in the Grande River Basin, Brazil using distributed modeling. Catena 2009, 79, 49-59. [CrossRef]

33. Hernando, D.; Romana, M.G. Estimating the rainfall erosivity factor from monthly precipitation data in the Madrid Region (Spain). J. Hydrol. Hydromech. 2015, 63, 55-62. [CrossRef]

34. Meddi, M.; Toumi, S.; Assani, A.A. Spatial and temporal variability of the rainfall erosivity factor in Northern Algeria. Arab. J. Geosci. 2016, 9. [CrossRef]

35. Sadeghi, S.H.; Tavangar, S. Development of stational models for estimation of rainfall erosivity factor in different timescales. Nat. Hazards 2015, 77, 429-443. [CrossRef]

36. Fan, J.R.; Chen, Y.; Yan, D.; Guo, F.F. Characteristics of rainfall erosivity based on tropical rainfall measuring mission data in Tibet, China. J. Mt. Sci-Engl. 2013, 10, 1008-1017. [CrossRef]

37. Zhang, W.B.; Fu, J.S. Rainfall Erosivity Estimation under Different Rainfall Amount. Resour. Sci. 2003, 25, 35-41. (In Chinese)

38. Angulo-Martinez, M.; Begueria, S. Estimating rainfall erosivity from daily precipitation records: A comparison among methods using data from the Ebro Basin (NE Spain). J. Hydrol. 2009, 379, 111-121. [CrossRef]

39. Zhang, W.B.; Xie, Y.; Liu, B.Y. Spatial distribution of rainfall erosivity in China. J. Mt. Sci. 2003, 21, 33-40. (In Chinese)

40. Ballabio, C.; Borrelli, P.; Spinoni, J.; Meusburger, K.; Michaelides, S.; Begueria, S.; Klik, A.; Petan, S.; Janecek, M.; Olsen, P.; et al. Mapping monthly rainfall erosivity in Europe. Sci. Total Environ. 2017, 579, 1298-1315. [CrossRef] [PubMed] 
41. Qin, W.; Guo, Q.K.; Zuo, C.Q.; Shan, Z.J.; Ma, L.; Sun, G. Spatial distribution and temporal trends of rainfall erosivity in mainland China for 1951-2010. Catena 2016, 147, 177-186. [CrossRef]

42. Hamlaoui-Moulai, L.; Mesbah, M.; Souag-Gamane, D.; Medjerab, A. Detecting hydro-climatic change using spatiotemporal analysis of rainfall time series in Western Algeria. Nat. Hazards 2013, 65, 1293-1311. [CrossRef]

43. Panagos, P.; Ballabio, C.; Borrelli, P.; Meusburger, K.; Klik, A.; Rousseva, S.; Tadic, M.P.; Michaelides, S.; Hrabalikova, M.; Olsen, P.; et al. Rainfall erosivity in Europe. Sci. Total Environ. 2015, 511, 801-814. [CrossRef] [PubMed]

44. Klik, A.; Haas, K.; Dvorackova, A.; Fuller, I.C. Spatial and temporal distribution of rainfall erosivity in New Zealand. Soil Res. 2015, 53, 815-825. [CrossRef]

45. Bonilla, C.A.; Vidal, K.L. Rainfall erosivity in central Chile. J. Hydrol. 2011, 410, 126-133. [CrossRef]

46. Ramos, M.C.; Durán, B. Assessment of rainfall erosivity and its spatial and temporal variabilities: Case study of the Penedes Area (NE Spain). Catena 2014, 123, 135-147. [CrossRef]

47. Xie, Y.; Yin, S.Q.; Liu, B.Y.; Nearing, M.A.; Zhao, Y. Models for estimating daily rainfall erosivity in China. J. Hydrol. 2016, 535, 547-558. [CrossRef]

48. Yin, S.; Xie, Y.; Liu, B.; Nearing, M.A. Rainfall erosivity estimation based on rainfall data collected over a range of temporal resolutions. Hydrol. Earth Syst. Sci. 2015, 19, 4113-4126. [CrossRef]

49. Yang, F.B.; Lu, C.H. Spatiotemporal variation and trends in rainfall erosivity in China's dryland region during 1961-2012. Catena 2015, 133, 362-372. [CrossRef]

50. Li, Q.F.; Yu, M.X.; Lu, G.B.; Cai, T.; Bai, X.; Xia, Z.Q. Impacts of the Gezhouba and Three Gorges reservoirs on the sediment regime in the Yangtze River, China. J. Hydrol. 2011, 403, 224-233. [CrossRef]

51. Guan, Y.H.; Zheng, F.L.; Zhang, X.C.; Wang, B. Trends and variability of daily precipitation and extremes during 1960-2012 in the Yangtze River Basin, China. Int. J. Climatol. 2017, 37, 1282-1298. [CrossRef]

52. Chen, H.P.; Sun, J.Q.; Chen, X.L.; Zhou, W. CGCM projections of heavy rainfall events in China. Int. J. Climatol. 2012, 32, 441-450. [CrossRef]

53. Wang, H.J. Coauthors, Extreme Climate in China: Facts, Simulation and Projection. Meteorol. Z. 2012, 21, 279-304. [CrossRef]

54. Fan, L.J.; Chen, D.L. Trends in extreme precipitation indices across China detected using quantile regression. Atmos. Sci. Lett. 2016, 17, 400-406. [CrossRef]

55. Chaplot, V. Impact of spatial input data resolution on hydrological and erosion modeling: Recommendations from a global assessment. Phys. Chem. Earth 2014, 67-69, 23-35. [CrossRef]

56. Arabi, M.; Govindaraju, R.S.; Hantush, M.M.; Engel, B.A. Role of watershed subdivision on modeling the effectiveness of best management practices with SWAT. J. Am. Water Resour. Assoc. 2006, 42, 513-528. [CrossRef]

57. Ma, L.; Jiang, G.H.; Zuo, C.Q.; Qiu, G.Y.; Huo, H.G. Spatial and temporal distribution characteristics of rainfall erosivity changes in Jiangxi Province over more than 50 years. Trans. CSAE 2009, 25, 61-68. (In Chinese)

58. Huang, J.; Sun, S.L.; Zhang, J.C. Detection of trends in precipitation during 1960-2008 in Jiangxi Province, Southeast China. Theor. Appl. Climatol. 2013, 114, 237-251. [CrossRef]

59. Ye, X.C.; Zhang, Q.; Liu, J.; Li, X.H.; Xu, C.Y. Distinguishing the relative impacts of climate change and human activities on variation of streamflow in the Poyang Lake catchment, China. J. Hydrol. 2013, 494, 83-95. [CrossRef]

60. Xiao, L.L.; Yang, X.H.; Chen, S.X.; Cai, H.Y. An assessment of erosivity distribution and its influence on the effectiveness of land use conversion for reducing soil erosion in Jiangxi, China. Catena 2015, 125, 50-60. [CrossRef]

61. Shankman, D.; Keim, B.D.; Song, J. Flood frequency in China's poyang lake region: Trends and teleconnections. Int. J. Climatol. 2006, 26, 1255-1266. [CrossRef]

62. Hu, Q.F.; Yang, D.W.; Wang, Y.T.; Yang, H.B. Accuracy and spatio-temporal variation of high resolution satellite rainfall estimate over the Ganjiang River Basin. Sci. China Technol. Sci. 2013, 56, 853-865. [CrossRef]

63. Zhang, Y.Q.; You, Q.L.; Lin, H.B.; Chen, C.C. Analysis of dry/wet conditions in the Gan River Basin, China, and their association with large-scale atmospheric circulation. Glob. Planet Chang. 2015, 133, 309-317. [CrossRef] 
64. Li, X.H.; Zhang, Q.; Xu, C.Y. Suitability of the TRMM satellite rainfalls in driving a distributed hydrological model for water balance computations in Xinjiang catchment, Poyang Lake Basin. J. Hydrol. 2012, 426-427, 28-38. [CrossRef]

65. Li, X.H.; Yao, J.; Li, Y.L.; Zhang, Q.; Xu, C.Y. A modeling study of the influences of Yangtze River and local catchment on the development of floods in Poyang Lake, China. Hydrol. Res. 2016, 47, 102-119. [CrossRef]

66. Li, X.H.; Zhang, Q.; Zhang, D.; Ye, X.C. Investigation of the drought-flood abrupt alternation of streamflow in Poyang Lake catchment during the last 50 years. Hydrol. Res. 2017, 48, 1402-1417. [CrossRef]

67. Kinnell, P.I.A. Event soil loss, runoff and the universal soil loss equation family of models: A review. J. Hydrol. 2010, 385, 384-397. [CrossRef]

68. Dabney, S.M.; Yoder, D.C.; Vieira, D.A.N.; Bingner, R.L. Enhancing RUSLE to include runoff-driven phenomena. Hydrol. Process. 2011, 25, 1373-1390. [CrossRef]

69. Wang, C.H.; Li, J.; Li, X.L.; Xu, X.G. Analysis on quasi-periodic characteristics of precipitation in recent 50 years and trend in next 20 years in China. Arid Zone Res. 2012, 29, 1-10. (In Chinese)

70. Gilbert, R.O. Statistical Methods for Environmental Pollution Monitoring; Van Nostrand Reinhold Co.: New York, NY, USA, 1987.

71. Salmi, T.; Maata, A.; Antilla, P.; Ruoho-Airola, T.; Amnell, T. Detecting Trends of Annual Values of Atmospheric Pollutants by the Mann-Kendall Test and Sen's Slope Estimates-The Excel Template Application Makesens; Finnish Meteorological Institute: Helsinki, Finland, 2002.

72. Schmidt, S.; Alewell, C.; Panagos, P.; Meusburger, K. Regionalization of monthly rainfall erosivity patterns in Switzerland. Hydrol. Earth Syst. Sci. 2016, 20, 4359-4373. [CrossRef]

73. Li, H.; Chen, X.L.; Lim, K.J.; Cai, X.B.; Sagong, M. Assessment of soil erosion and sediment yield in Liao watershed, Jiangxi Province, China, using USLE, GIS, and RS. J. Earth Sci.-China 2010, 21, 941-953.

74. Routschek, A.; Schmidt, J.; Enke, W.; Deutschlaen, T. Future soil erosion risk-Results of GIS-based model simulations for a catchment in Saxony/Germany. Geomorphology 2014, 206, 299-306. [CrossRef]

75. Mukundan, R.; Pradhanang, S.M.; Schneiderman, E.M.; Pierson, D.C.; Anandhi, A.; Zion, M.S.; Matonse, A.H.; Lounsbury, D.G.; Steenhuis, T.S. Suspended sediment source areas and future climate impact on soil erosion and sediment yield in a New York City water supply watershed, USA. Geomorphology 2013, 183, 110-119. [CrossRef]

76. Gao, T.; Xie, L. Spatiotemporal changes in precipitation extremes over Yangtze River basin, China, considering the rainfall shift in the late 1970s. Glob. Planet Chang. 2016, 147, 106-124. [CrossRef]

77. Wang, Y.Q.; Zhou, L. Observed trends in extreme precipitation events in china during 1961-2001 and the associated changes in large-scale circulation. Geophys. Res. Lett. 2005, 32, 109707. [CrossRef]

78. Zhang, Q.; Xu, C.Y.; Zhang, Z.X.; Chen, Y.Q.D.; Liu, C.L.; Lin, H. Spatial and temporal variability of precipitation maxima during 1960-2005 in the Yangtze River Basin and possible association with large-scale circulation. J. Hydrol. 2008, 353, 215-227. [CrossRef]

79. You, Q.L.; Kang, S.C.; Aguilar, E.; Pepin, N.; Flugel, W.A.; Yan, Y.P.; Xu, Y.W.; Zhang, Y.J.; Huang, J. Changes in daily climate extremes in china and their connection to the large scale atmospheric circulation during 1961-2003. Clim. Dyn. 2011, 36, 2399-2417. [CrossRef]

80. Ye, X.C.; Li, X.H.; Liu, J.; Xu, C.Y.; Zhang, Q. Variation of reference evapotranspiration and its contributing climatic factors in the Poyang Lake Catchment, China. Hydrol. Process. 2014, 28, 6151-6162. [CrossRef]

81. Zhang, D.; Hong, H.Y.; Zhang, Q.; Nie, R. Effects of climatic variation on pan-evaporation in the Poyang Lake Basin, China. Clim. Res. 2014, 61, 29-40. [CrossRef]

82. Prein, A.F.; Rasmussen, R.M.; Ikeda, K.; Liu, C.H.; Clark, M.P.; Holland, G.J. The future intensification of hourly precipitation extremes. Nat. Clim. Chang. 2017, 7, 48-52. [CrossRef]

83. Zhang, Q.; Xiao, M.Z.; Singh, V.P.; Wang, Y.Q. Spatiotemporal variations of temperature and precipitation extremes in the Poyang Lake Basin, China. Theor. Appl. Climatol. 2016, 124, 855-864. [CrossRef]

84. Richardson, C.W.; Foster, G.R.; Wright, D.A. Estimation of erosion index from daily rainfall amount. Trans. ASAE 1983, 26, 153-156. [CrossRef]

(C) 2018 by the authors. Licensee MDPI, Basel, Switzerland. This article is an open access article distributed under the terms and conditions of the Creative Commons Attribution (CC BY) license (http:/ / creativecommons.org/licenses/by/4.0/). 